\title{
A new species of the genus Actium (Coleoptera: Staphylinidae: Pselaphinae) from boreal old- growth forests of Quebec, Canada1
}

\author{
Donald S Chandler² \\ Department of Zoology, University of New Hampshire, Durham, New Hampshire 03824, \\ United States of America \\ Pierre Paquin \\ Department of Biology, San Diego State University, 5500 Campanile Drive, San Diego, \\ California 92182-4614, United States of America
}

The Canadian Entomologist 136: 753 - 757 (2004)

\begin{abstract}
A new species, Actium abitibiense Chandler et Paquin sp. nov., is described and is associated with old-growth boreal forests in western Quebec.

Chandler DS, Paquin P. 2004. Une nouvelle espèce du genre Actium (Coleoptera : Staphylinidae : Pselaphinae) provenant des forêts boréales anciennes du Québec. The Canadian Entomologist 136 : 753-757.
\end{abstract}

Résumé-Une nouvelle espèce, Actium abitibiense Chandler et Paquin sp. nov., est décrite. Cette espèce est associée aux forêts boréale anciennes de l'ouest du Québec.

\section{Introduction}

At present 41 species of the North American genus Actium Casey, 1886 (Coleoptera: Staphylinidae: Pselaphinae) are known, with most of these species restricted to California and the Pacific Northwest. One species, A. impunctatum (Brendel, 1865), is found from Pennsylvania to North Carolina in the Appalachian Mountains, while four other species are recorded from southern Mexico, Jamaica, and Puerto Rico. The generic assignment of these latter four species should be checked. Members of this genus are typically extracted from coniferous or deciduous leaf litters and rotten logs, or are found beneath the bark of dead trees. Actium abitibiense sp. nov. is described from the forests of western Quebec and is the only pselaphine known solely from Canada. All other Canadian species are also known to occur in the United States.

\section{Ecological comments}

The specimens were collected during an extensive sampling program to gather data on the beetle fauna of two important ecological zones of the boreal forest of western Quebec: (1) the mixed boreal succession found in the southern portion of the boreal zone; and (2) the black spruce forest, which is found at higher latitudes. The mixed boreal succession is characterized by the transition from deciduous to coniferous trees with increasing age of the forest since the last forest fire, which determines the resulting

${ }^{1}$ This is Scientific Contribution 2203 from the New Hampshire Agricultural Experiment Station.

${ }^{2}$ Corresponding author (e-mail: dsc1@ cisunix.unh.edu). 
initial flora. The younger stages of the succession (less than 100 years old) are dominated by quaking aspen (Populus tremuloides Michx.; Salicaceae), thus forming a deciduous forest; the intermediate stages (100-200 years old) are characterized by balsam fir (Abies balsamea (L.) P. Mill.; Pinaceae), white spruce (Picea glauca (Moench) Voss; Pinaceae), paper birch (Betula papyrifera Marsh.; Betulaceae), and some quaking aspen, forming a mixed forest; and the older stages (200 years and older) are dominated by white cedar (Thuja occidentalis L.; Cupressaceae) and balsam fir to form a coniferous forest (Bergeron 2000).

All specimens except one were collected at two sites (Lake Duparquet, $48^{\circ} 49^{\prime} 30^{\prime \prime} \mathrm{N}, 79^{\circ} 19^{\prime} 30^{\prime \prime} \mathrm{W}$; Lake Labyrinthe, $48^{\circ} 13^{\prime} 35^{\prime \prime} \mathrm{N}, 79^{\circ} 27^{\prime} 47^{\prime \prime} \mathrm{W}$ ) found within the oldest stage of the mixed boreal succession (dominated by white cedar and balsam fir) in which some old, dead, and decaying paper birch are also found. These sites were 235 and 407 years old at the time of sampling. The remaining specimen was taken in the northern portion of the boreal forest, where black spruce (Picea mariana (P. Mill.) B.S.P.) dominates all successional stages, at a 300-year-old site that is among the oldest successional forest sites for this forest system in this particular region. This record is the northernmost $\left(49^{\circ} 32^{\prime} 41^{\prime \prime} \mathrm{N}, 79^{\circ} 19^{\prime} 00^{\prime \prime} \mathrm{W}\right)$ for the new species described herein, but this species may occur at higher latitudes, since black spruce forests extend north to the treeline. Bergeron (2000) and Bergeron et al. (2001) performed extensive studies of the fire history and age of the forest for these ecological regions using dendrochronological methods based on the oldest available trees. Some stands used in our study were the same as those studied by these authors, and the ages of the forest stands were taken directly from these papers.

The specimen data suggest that adults are active during the entire snow-free period, which extends from mid-May until late September at these latitudes, although activity seems to occur rather early and late in the season. Most specimens were collected using Berlese extractors and were taken from bark and polypore fungi, a senescent birch, or bark and rotting cedar logs. The number of specimens found is rather low considering the intensity of the sampling efforts (Paquin and Dupérré 2001), especially considering the $4500 \mathrm{~L}$ of organic matter processed by Berlese extractors from forests of all ages in this area.

There are a number of pselaphine species from Quebec, Canada (Paquin and Dupérré 2001), New Hampshire (Chandler 1987), the southeastern United States (Carlton and Chandler 1994), England (Garland 1983), Italy (Vit 1985; Seriani 1987; Balleto and Casale 1991), and Japan (Tanokuchi 1988) that have been shown to be or are thought to be most abundant in old-growth or mature forests. All individuals of the new species described herein were taken from old forests, and it is possible that this species may be an indicator of old-growth forests. Despite the lack of statistical support, Paquin (2001) suggested that such rarely encountered species should not be excluded as old-growth indicators. Ecological observations and collections provide valuable starting points for drawing attention to those species potentially restricted to vulnerable habitats such as old-growth forests.

The specimens are deposited in the Canadian National Collection, Agriculture Canada, Ottawa, Ontario, Canada, (CNC) and the collection of DS Chandler (DSC).

\section{Actium abitibiense Chandler et Paquin sp. nov.} (Figs. 1-4)

\section{Specimens examined}

Holotype: male. Abitibi-ouest: Lake Duparquet $\left(48^{\circ} 49^{\prime} 30^{\prime \prime} \mathrm{N} ; 7^{\circ} 19^{\prime} 30^{\prime \prime} \mathrm{W}\right)$ in white cedar/balsam fir forest, 9/16.vi.1996, pitfall, sample 2692, P Paquin (CNC). 

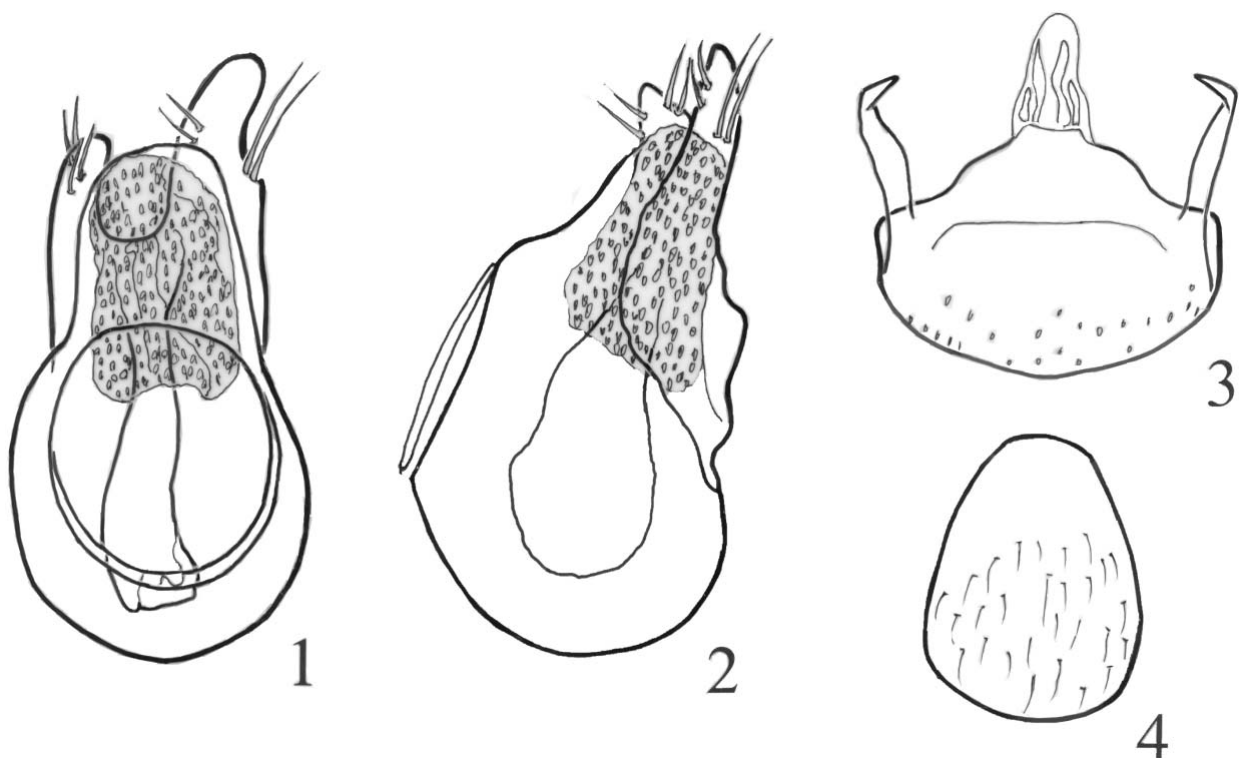

Figures 1-4: Actium abitibiense. 1, aedeagus (0.28 mm long), dorsal view; 2, aedeagus, left lateral view; 3, sternite IX (penial plate), male $(0.12 \mathrm{~mm}$ long), ventral view; 4 , sternite VIII, female $(0.16 \mathrm{~mm}$ long), ventral view.

Paratypes: 9 (CNC, DSC). Abitibi-ouest: Lake Duparquet $\left(48^{\circ} 49^{\prime} 30^{\prime \prime} \mathrm{N} ; 79^{\circ} 19^{\prime} 30^{\prime \prime} \mathrm{W}\right)$ in white cedar/balsam fir forest: $10^{x}$, 29.v./5.vi.1994, Malaise trap pan, sample 273, P Paquin; $2 \sigma^{\star}, 1$ ㅇ, 22.viii.1997, Berlese sample of bracket fungus on birch, sample S104, P Paquin; $1 \sigma^{\pi}, 1$ ㅇ, 19.ix.1996, Berlese sample of mosses on dead birch, sample M-94, P Paquin. Témiscamingue: Lake Labyrinthe $\left(48^{\circ} 13^{\prime} 35^{\prime \prime} \mathrm{N} ; 79^{\circ} 27^{\prime} 47^{\prime \prime} \mathrm{W}\right)$ in white cedar/balsam fir forest: $1 \sigma^{\star}$, 24.vii.1996, Berlese sample of birch bark, sample M-35, P Paquin; 1 ㅇ, 18.viii.1996, Berlese sample of dead white cedar, sample M-74, P Paquin. Jamésie (James Bay): Chemin Casa-Berardi $\left(49^{\circ} 32^{\prime} 41^{\prime \prime} \mathrm{N}\right.$; $\left.79^{\circ} 19^{\prime} 00^{\prime \prime} \mathrm{W}\right)$ in black spruce forest: 1 ㅇ, 22/29.vi.1997, Malaise trap pan, sample 5006, P Paquin.

\section{Description}

Length 1.60-1.76 mm. Body orange-brown; setae moderately dense, decumbent. Head with vertexal foveae setose; antennomere XI as long as previous five, IX and X lenticular, strongly transverse, IX slightly wider than VIII; gular area with approximately 30 clubbed setae.

Pronotum with lateral margins evenly converging from middle to base, margins in basal half denticulate; deep antebasal sulcus biarcuate, sulcus slightly constricted medial to lateral antebasal foveae. Elytra with three basal foveae; discal stria extending past elytral midpoint. First tergite with discal carinae at base short, difficult to see. Profemora with basal two thirds bearing setose denticles in shallow, narrow impression on venter.

Males with about 70 facets in each eye; pro- and mesofemora swollen, subequal in size, clearly broader than metafemora; male mesotrochanters slightly angulate at middle on posterior margins; mesotibiae with small preapical tubercle; basal sternites lacking lateral modifications. Sternite IX (penial plate) symmetrical, elongate, trapezoidal, with corners broadly rounded, setose area lacking boundary; aedeagus asymmetrical, with setae at or near apex of both parameres. 
Females with about 30 facets in each eye; profemora somewhat enlarged, broader than meso- and metafemora. Sternite VIII with apex broadly rounded.

\section{Relationships}

This species presents problems when using the key provided by Grigarick and Schuster (1971) in their revision of Actium. The presence of three basal elytral foveae leads this species to the couplet separating the fastigium group (with distinct setose areas laterally on visible sternites II-III) from the californicum group (with depressed areas laterally on these sternites), but the male abdominal sternites of A. abitibiense are shallowly convex and lack modifications. A comparison of this species with species in the two groups places A. abitibiense closest to A. retractum Casey, 1908, a member of the fastigium group from the Pacific Northwest. Both species share the evenly converging denticulate lateral margins of the pronotum, the biarcuate antebasal sulcus of the pronotum, setose vertexal foveae, the equally swollen male pro- and mesofemora, and the broadly rounded apex of female sternite VIII.

Actium abitibiense is easily distinguished from $A$. retractum by their widely disjunct distributions and, for males of $A$. abitibiense, by the lack of modifications on visible sternites II-III, the rounded trapezoidal form of sternite IX (penial plate), the lack of a circular carina defining the setose area on sternite IX, and the relatively simple aedeagus. Males of $A$. retractum have small setose areas laterally on visible sternites IIIII; sternite IX is irregularly circular and has the setose area clearly defined by a circular carina slightly wider than long; and the aedeagus has the left paramere forked.

\section{Acknowledgments}

We express our gratitude to N Dupérré (Laval, Quebec, Canada) for her help in the field and the laboratory, and HD Cameron (University of Michigan) for his Latin expertise. This research was funded by a scholarship from FCAR Québec (Fonds pour la formation de chercheurs et l'aide à la recherche) to P Paquin. The GREFi (Groupe de Recherche en Écologie Forestière inter-universitaire) and GRIL (Groupe de Recherche inter-universitaire en Limnologie) provided material support and budgets for field assistance. We thank JF Burger and PC Johnson (University of New Hampshire) for comments on the paper.

\section{References}

Balleto E, Casale A. 1991. Mediterranean insect conservation. pp 121-42 in NM Collins, JA Thomas (Eds), The conservation of insects and their habitats. London: Academic Press

Bergeron Y. 2000. Species and stand dynamics in the mixed woods of Quebec's southern boreal forest. Ecology 81(6): 1500-16

Bergeron Y, Gauthier S, Kafka V, Lefort P, Lesieur D. 2001. Natural fire frequency for the eastern Canadian boreal forest: consequences for sustainable forestry. Canadian Journal of Forest Research 31: 384-91

Carlton CE, Chandler DS. 1994. Revision of the Nearctic genus Pseudactium Casey (Coleoptera: Pselaphidae: Euplectinae). The Coleopterists Bulletin 48: 171-90

Chandler DS. 1987. Species richness and abundance of Pselaphidae (Coleoptera) in an old-growth and 40year-old forest in New Hampshire. Canadian Journal of Zoology 65: 608-15

Garland SP. 1983. Beetles as primary woodland indicators. The Sorby Record 21

Grigarick AA, Schuster RO. 1971. A revision of Actium Casey and Actiastes Casey (Coleoptera: Pselaphidae). University of California Publications in Entomology 67

Paquin P. 2001. Huit espèces d'insectes associées aux forêts matures et anciennes. Le Naturaliste Canadien 125(3): $115-21$

Paquin P, Dupérré N. 2001. Beetles of the boreal forest: a faunistic survey carried out in western Quebec. Proceedings of the Entomological Society of Ontario 132: 57-98 
Seriani M. 1987. Idee por lo studio dell'entomofauna dei boschi planiziali friulani ed osservazioni su alcune specie di Coleotteri raccolte nella lettiera. Biogeographia 13: 699-712

Tanokuchi Y. 1988. Relation between pselaphid beetles and plant communities in the beech forest area of Oku-Nikko, central Japan. Transactions of the Shikoku Entomological Society 19: 73-81

Vit S. 1985. Quelque éléments de la faune Coléoptérologique résistant à la destruction de l'ancienne forêt de pantano de Policoro (Basilicata). Annali del Museo Civico di Storia Naturale di Genova 85: 307-31

(Received: 6 November 2003; accepted: 27 September 2004) 